\title{
The Effect of Inquiry Method Assisted by Audiovisual Media and Learning Motivation on Writing News Text Skills
}

\author{
Sef Afriadi ${ }^{1, *}$ Atmazaki $^{1}$ Irfani Basri ${ }^{1}$ \\ ${ }^{1}$ Faculty of Language and Art, Padang State University, Padang, Indonesia \\ ${ }^{*}$ Corresponding author. Email: afriadisef01@gmail.com
}

\begin{abstract}
This type of research is a quantitative study using a quasy experiment method. Research design is factorial design. The population of this study was all eight grade students of Public Middle School 6 Padang totaling one hundred and eighty-five students. Sampling was done by random sampling technique and obtained class VIII.1 as an experimental class with a total of thirty students and class VIII.2 as a control class with a total of thirty students. The instrument of this study, namely learning motivation questionnaire and performance test skills for writing text of news. Analyzing data is done descriptively in accordance with the concept of experimental research. The results of this study are as follows. First, the skill to write the text of news in the experimental class and the control class. Second, the text of the news writing skill result and the experimental class students who have a grade control learning motivation high and low learning motivation. Third, there is no interaction between inquiry method assisted by audiovisual media and learning motivation in influencing the writing of news texts.
\end{abstract}

\section{Keywords: news writing skill, motivation to learn, method inquiry, audiovisual media}

\section{INTRODUCTION}

Writing is a language skill. Writing skills are important for students to master in the learning process at school, especially in learning Indonesian language and literature at the SMP / MTs level. Writing is an activity to express the contents of a person's thoughts, ideas or opinions, ideas or feelings [1]. Writing is also a productive and expressive activity [4]. Writing activities are an integral part of the entire learning process experienced by students at school. Writing skills do not come suddenly, but writing needs to be trained continuously [15].

There are many students who still have difficulty writing even though learning to write has been given since they were in elementary school. This is also evidenced by several previous studies from Indonesia such as, (Kurnia, 2005, p. 73); [2]; [10] but also from Iran [12], America [7]; [8], which reveals that difficulty in writing is caused by fear and anxiety. They think writing is an individual work that must produce a product. As a result, students do not like writing activities. In addition, other difficulties experienced by students such as how to find topics, organize sentences effectively, and how to write. Students who are not skilled at writing will face difficulties when expressing their ideas, even though there are lots of ideas in their minds, they will have difficulty expressing them in written form. Especially for novice writers, writing is not an easy job. This is because writing requires complex skills.

One of the texts studied by junior high school grade VIII students in the 2013 Curriculum is a news text. The skills in writing news texts are found in the 1st Core Competency (KI) which reads respect and appreciate the teachings of the religion he adheres to. The 4.1th Basic Competency (KD) reads summing up the content of the news (boasting and motivating) that is read and heard.

Based on the results of pre-research observations that have been carried out at SMP Negeri 6 Padang with Mrs. Gusmalinda, S.Pd, in general students experience problems in writing news texts. These problems are as follows. First, the students' low writing skills due to lack of practice and practice in writing. Writing skills do not come suddenly, but must go through sufficient practice and practice. Writing exercises are not only obtained at school, but can also be obtained at home and others. Second, students do not understand the criteria for writing news texts, so that students are confused about expressing ideas in text form. This happened when the teacher gave the task to write news texts, there were still many students who were silent when ordered to write the text. Third, the structure of the news text written by students still does not meet the criteria for developing a news text structure. Fourth, in terms of writing the language element of the news text. Students do not understand linguistic elements of text such as cojunctions, 
pronouns (pronouns), effective sentences, repetition (repetition) and the use of Indonesian Spelling (EBI). Most students only focus on the structure of the text so that language elements are often left aside. Fifth, the lack of use of learning facilities such as infocus, laptop, and so on. Sixth, the learning methods used by teachers in learning still use one-way learning. Students simultaneously do two activities, namely listening to and recording what the teacher says. These problems certainly have an impact on the grades obtained by students.

Starting from the problems and objectives of learning Indonesian language and literature listed in the 2013 curriculum, this study intends to describe the writing skills of class VIII students at SMPN 6 Padang, using inquiry learning methods assisted by audiovisual media through experimental research in order to motivate students to desire develop the knowledge it has. This research is based on the assumption that interesting and fun learning will stimulate students to follow the learning well. One of the interesting lessons is to use a variety of methods, techniques, strategies and media.

Based on this description, this research is important to do in order to motivate students to be skilled in writing news texts. The author considers that the learning method and student learning motivation are low, it is suspected that there are two things that greatly affect student learning outcomes. To see the real thing, the author raises the title of this study, namely The Effect of Audiovisual Media Assisted Inquiry Methods and Learning Motivation on News Text Writing Skills for Classroom Students. VIII SMPN 6 Padang .

\section{RESEARCH METHODS}

This research is a quantitative study using numbers. This research is said to be quantitative because the processed data is in the form of numbers. The numbers in this study were the scores of the learning motivation questionnaire and the scores of the eighth grade students' news text writing skills test at SMP Negeri 6 Padang. [1] argues that quantitative research is research that uses numbers starting from data collection, then data interpretation and finally the results. Furthermore, [14] states that quantitative research is research in which the research data is in the form of numbers and the analysis uses statistics.

The population in this study were students of class VIII SMP Negeri 6 Padang who were registered in the 2019/2020 school year. The population is large and more than 100 , it is necessary to take samples. Therefore, this study only uses two classes which will be designated as research samples. Sampling in this study was carried out by using random sampling technique. [11] states that random sampling is a randomly selected sample, each member of the population gets the same opportunity to be selected. The basic steps are to determine the class average. First, collect the daily test scores of class VIII students of SMP Negeri 6 Padang for the 2019/2020 academic year that are available to Indonesian language teachers. Second, perform a normality test using the Liliefors test. Third, perform a variant homogeneity test. Fourth, determine the experimental class and control class randomly by using a lottery technique. So, it can be obtained by class VIII.1 students as the experimental class and class VIII.2 as the control class. Based on the test for normality and homogeneity of the sample classes, the results of these two classes are normally distributed and homogeneous.

This research consists of three variables. First, the independent variable (independent variable) is an inquiry method assisted by audiovisual media. Second, the dependent variable (dependent variable) is the skill of writing news texts. Third, the moderator variable is learning motivation.

The data used in this study, namely (1) the score of the results of filling out the learning motivation questionnaire, (2) the score of the test results of the students' news text writing skills using the inquiry method assisted by audiovisual media and conventional methods, (3) the score of the test results for the writing of news text skills. using the inquiry method assisted by audiovisual media, and (4) the score of the test results of the writing news text skills using conventional methods.

\section{RESULTS AND DISCUSSION}

Based on the data analysis of the writing skills of the eighth grade students of SMP Negeri 6 Padang, it shows that students who are taught using inquiry methods assisted by audiovisual media as a whole and groups of students who are highly motivated to learn and have low learning motivation have differences from the results of the hypothesis testing conducted. Based on this, studies related to the theory stated in the previous section will be described, namely (1) students' news text writing skills taught using inquiry methods assisted by audiovisual media and lecture methods, (2) writing skills of students with high learning motivation with News text writing skills with low learning motivation, (3) the interaction between learning motivation and audiovisual media assisted inquiry methods in influencing news text writing skills.

\subsection{Student News Text Writing Skills Taught with Audiovisual Media Assisted Inquiry Methods and Lecture Methods}

The form of the tests carried out in the experimental class and the control class is the same, there is no difference in the form of the questions. The test is in the form of a performance test of writing news text skills. This test aims to see the difference and effect of the inquiry method assisted by audiovisual media on the learning outcomes of the eighth grade students' news text writing skills at SMP Negeri 6 Padang.

Based on the data analysis, the results of the news text writing skills test of students who were taught using the 
inkuri method assisted by audiovisual media were higher than the scores of students' news text writing skills taught by the lecture method. The highest score was obtained in the experimental class, namely 100 highest scores and 62.50 lowest scores and an average value of 83.85 while in the control class the highest score was obtained 95.83 and the lowest score was obtained 58.33 and the average value was 78.79. This shows that the value of the experimental class news text writing skills is higher than the control class.

Based on the acquisition of this value it is associated with the Minimum Completeness Criteria (KKM) for writing news text skills the same as the experimental class, namely 70. In the control class taught by the lecture method there were $75 \%$ who were complete and $25 \%$ who were incomplete, while in the experimental class the taught by the method of inquiry assisted by audiovisual media, there were $93.73 \%$ of students who completed and $6.25 \%$ of the students did not complete.

During the learning process, the two classes were given different treatment. The experimental class was taught using the inquiry method assisted by audiovisual media, while the control class was taught using the lecture method. In this case, a different learning atmosphere can be seen, students who are taught inquiry method assisted by audiovisual media are more enthusiastic and creative in the learning process. This is because the way you feel learning is different from before. Experimental class students are more active in asking questions related to the subject matter. In contrast to the control class, students are more silent in the learning process. Control class students do not feel there is any renewal in the learning process, so they are passive to ask and answer questions in the learning process.

The results of testing the first hypothesis indicate that in general the results of the test results of students' news text writing skills using the inquiry method assisted by audiovisual media were higher than the news text writing skills taught using the lecture method. The value obtained by students in the experimental class was higher than the value obtained by students in the control class. In addition, there is also a difference in the average value of the indicator between the experimental class and the control class.

The inquiry method has six steps according to the theory put forward by [13] on the implementation of learning as follows. First, orientation is a step to foster a responsive learning atmosphere or climate. In this step, the teacher conditions so that students are ready to carry out the learning process. The teacher stimulates and invites students to think about solving problems. Second, formulating a problem, namely a step that takes students to a problem containing a puzzle. The problem presented is a problem that challenges students to think about solving the puzzle. In the formulation of the problem, there must be an answer, and students are encouraged to find the right answer. The process of looking for answers is very important in inquiry learning, therefore through this process students will gain valuable experiences as an effort to develop mentally through the thought process. Third, formulate a hypothesis, namely a temporary answer to a problem that is being studied. As a temporary answer hypothesis needs to be tested for truth. Estimation as a hypothesis must have a solid basis for thinking, so that the hypothesis that is raised is rational and logical. One way that teachers can develop the ability to guess (hypothesize) for each child is by asking questions that can encourage students to be able to formulate temporary answers or be able to formulate various estimates of possible answers to a problem being studied.

Fourth, collecting data, namely the activity of capturing the information needed to test the proposed hypothesis. The process of collecting data not only requires strong motivation to learn, but also requires persistence and the ability to use its thinking potential. Therefore, the teacher's task and role in this stage is to ask questions that can encourage students to think about finding the information needed. Fifth, testing the hypothesis, namely the process of determining the answer that is considered acceptable in accordance with the data or information obtained based on arguments, but must be supported by the data found and can be found to be accounted for. Sixth, formulating conclusions, namely the process of describing the findings obtained based on the results of hypothesis testing. To reach accurate conclusions, the teacher should be able to show students which data is relevant. So the use of learning with an inquiry approach is that students will get a better understanding of learning Indonesian and will be more interested in learning Indonesian taught by the teacher. In the inquiry strategy, students are actively involved in finding a given problem. Students are focused on understanding the concepts in Indonesian language learning and improving students' scientific thinking process skills. So it is believed that the inquiry strategy can improve student learning outcomes and foster student interest in learning Indonesian.

Learning with the inquiry method assisted by audiovisual media determines the learning responsibilities of students. The teacher acts as a student facilitator. Students are more active than teachers. Students are active in asking questions about the material presented by the teacher and also students understanding the material provided, so that the students' news text writing skills score is higher than the control class. In the experimental class, the students' news text writing skills improved because they were given treatment using the inquiry method assisted by audiovisual media.

The audiovisual media assisted inquiry method is different from the lecture method. According to [3] the lecture method in practice uses one-way communication, in which the teacher provides explanations or delivers learning material to students orally. Teachers often spend time explaining the material in a book. In this case, the learning 
process is dominated by the teacher, not the students, so that students are not too active, because students do two activities at the same time, namely listening and recording what the teacher says. This will have an impact on students who have substandard knowledge who find it difficult to absorb the material presented by the teacher.

In accordance with the problems that occur, it can be seen that in learning students do listening and copying activities in books, so that students are less enthusiastic about asking questions. This results in students not having time to do independent activities to understand information on teaching materials and do classroom exercises.

Based on the description of the differences in treatment in each of these classes, it can be concluded that learning to write news texts using inquiry methods assisted by audiovisual media can affect the scores of students' news text writing skills to be better. Meanwhile, learning with the lecture method resulted in low news text writing skills, this was due to learning using the lecture method placing students as passive objects in learning, so students could not explore knowledge and skills extensively.

\subsection{News text writing skills that have high learning motivation and news text writing skills that have low learning motivation}

The results of testing the second hypothesis indicate that there are differences in the results of the writing skills of students who have high learning motivation and students who have low learning. This means that the results of the students' news text writing skills who have high learning motivation are higher than students who have low learning motivation in the experimental class and the control class. The value of writing news text skills for students with high learning motivation in the experimental class obtained the highest score of 100 and the lowest score was 75 with an average score of 85.41, while students who had low learning motivation had the highest score of 91.66 and the lowest score was 62.50 with an average value of 82.28. Furthermore, the score of writing news text skills for students with high learning motivation in the control class obtained the highest score of 95.83 and the lowest score was 62.50 with an average value of 81.76 while students who had low learning motivation had the highest score of 87.50 and the lowest value is 58.33 with an average value of 74.99 .

Obtaining this value shows that the inquiry method assisted by audiovisual media can be used in the learning process of writing news texts for students who have high learning motivation or low learning motivation. Students who have high learning motivation will automatically have high knowledge in writing news texts, so that it will be easy to follow each of the steps in the inquiry method assisted by audiovisual media. With high learning motivation, students will have the ease in writing texts. This can be realized because through learning motivation students will be more responsible and active in the learning process. This is in accordance with the opinion of [17] arguing that learning motivation is a psychological driving force within a person to be able to carry out learning activities and increase skills and experiences. Furthermore, motivation is an important factor in learning as well as a determinant of learning activities undertaken. Motivation to learn can be observed through activities and learning outcomes. Students who get good learning outcomes because of their persistence and have high learning motivation and students who get low learning outcomes can also be caused by low learning motivation. [6] explains that learning motivation provides motivation and enthusiasm in learning so that it can affect student learning activities and achievement.

Based on this, it can be concluded that with the existence of student learning motivation, students will have the enthusiasm to develop ideas or opinions regarding the material being discussed and which will be discussed in groups.

3.3 The Interaction Between Learning Motivation and Inquiry Methods Assisted by Audiovisual Media in Influencing News Text Writing Skills

Interaction occurs when the effect of one factor depends on other factors in influencing something. This is in accordance with the opinion of Irianto [5]. This means that each of the factors between the inquiry method assisted by audiovisual media and learning motivation is thought to be interrelated in influencing news text writing skills. The interaction process between variables is explained as follows.

However, after the data analysis test with two-way ANOVA (factorial by level $2 \times 2$ ) the third hypothesis testing can be concluded, that there is no interaction of inquiry method assisted by audiovisual media with learning motivation in influencing news text writing skills. That is, after data analysis was carried out it was proven that there were some students who were motivated to learn high writing scores and vice versa. However, the overall average score for the learning of news text writing skills for students who have high learning motivation is higher than students who have low learning motivation. As previously stated, interaction is the effect of the treatment of certain learning methods. However, learning motivation does not necessarily determine success in writing news text skills.

There was no interaction between the inquiry method assisted by audiovisual media and learning motivation in influencing the skills to write news texts. It can be concluded that each of the factors of the inquiry method assisted by audiovisual media and learning motivation are not interdependent with each other in influencing the learning outcomes of news text writing skills in both the experimental class and the control class. Even so, the audiovisual media assisted inquiry method seemed to be more effective at both levels of learning motivation. In other words, it is also a tool for previous research that the inquiry method assisted by audiovisual media can be applied to 
students who have high learning motivation and low learning motivation.

\section{CONCLUSIONS AND SUGGESTIONS}

Based on the data analysis and discussion that has been stated in Chapter IV, it can be concluded that the inquiry method assisted by audiovisual media affects the learning outcomes of writing news texts. First, the results of the test for the skills of writing news texts taughts by the inquiry method assisted by audiovisual media were higher than for students taught using the lecture method. This is because the treatment given by using the inquiry method assisted by audiovisual media has advantages such as students are more able to develop and apply the knowledge that has been obtained and use the potential learning resources that exist around them. Second, the results of the writing skills test of students who have high learning motivation who are taught by inquiry method assisted by audiovisual media are higher than those who have high learning motivation taught by lecture method. Third, the writing skills test results of students who have low learning motivation who are taught by the inquiry method assisted by audiovisual media are higher than those who have low learning motivation taught by the lecture method. Fourth, there is no interaction between inquiry method assisted by audiovisual media and learning motivation in influencing the writing skills of class VIII students of SMP Negeri 6 Padang.

This means that without learning motivation, the inquiry method assisted by audiovisual media still affects students' learning outcomes of news text writing skills. Furthermore, students who have high or low learning motivation can be taught using the audiovisual media assisted inquiry method. As for suggestions regarding the use of inquiry methods assisted by audiovisual media are submitted to teachers and further researchers. First, students are expected not to consider writing lessons especially on writing news text material to be difficult, because the application of inquiry methods assisted by audiovisual media is one solution to improve student learning outcomes for the better. Through learning using this method students easily gain knowledge such as understanding news texts, text structure, text elements and steps to write text. Through this method students can participate actively in the learning process. Second, through analysis and use of inquiry methods assisted by audiovisual media, teachers are expected to be able to apply creative and innovative learning methods, one of which is the inquiry method assisted by audiovisual media in Indonesian subjects. Through this method, it can improve the results of writing news texts, and can help students understand the material deeply and can be attached to students permanently. Third, for future researchers, the results of this researcher can be proposed as a comparison or reference for considering and carrying out experimental research related to writing news texts using the audiovisual media assisted inquiry method.

\section{REFERENCES}

[1]Arikunto, Suharsimi. (2002). ProsedurPenelitian. Jakarta: Rhineka Cipta.

[2]Aji, W, N. (2016). Peningkatan Keterampilan Menulis Teks Eksposisi dengan Metode Inquiry Discovery Learning dan Penggunaan Media Video pada Siswa Kelas VII G SMPN 3 Colomadu. Magistra. 2(95), 1-11.

[3]Djafar, T.Z. (2001). Kontribusi Strategi Belajar Mengajar. Jakarta: Rineka Cipta.

[4] Fitriyani. (2015). "Penguasaan Kalimat Efektif dan Penguasaan Diksi dengan Kemampuan Menulis Eksposisi pada Siswa SMP”. Jurnal 1(2) 129-139.

[5] Irianto, A. (2004). Statistik Pendidikan. Gadjah Mada: University Press.

[6] Iskandar. (2009). Psikologi Pendidikan: Sebuah Orientasi Baru. Ciputat: GP Press.

[7] Kellogg, R, T. (2008). Training Writing Skills: A Cognitive Developmental Perspekctive. Journal of Writing Research, 1(1), 1-26.

[8] Kellogg, R, T., Raulerson, B, A. (2007). Improving the Writing Skills of College Students. Psychonomics Bulletin \& Review, 14(2), 237-242.

[9] Kurnia. (2015). Penerapan Model Problem Based Learning untuk Meningkatkan Kemampuan Menulis Teks Eksposisi pada Siswa Kelas IIS-4 SMA Negeri 8 Makasar. Jurnal Pepatuzdu, 9(1), 72-79.

[10] Linda, W, Gusti, A, A. (2017). Keterampilan Menulis Kreatif Cerpen Menggunakan Media Audio Siswa Kelas XII SMAN 1 Kecamatan Payakumbuh. Jurnal Penelitian Pendidikan, 37(1), 89-97.

[11] Ridwan. (2011). Dasar-dasar Statistik. Bandung: Alfabeta.

[12] Shokrpour, N., kezhavars, N., Jafari, S.M. "The effect of peer review on writing skill of efl student". Khazar Journal of Humanities and Social Sciences, 24-35.

[13] Sanjaya, Wina. (2006). Strategi Pembelajaran Berorientasi Standar Proses Pendidikan. Jakarta: Kencana. [14] Sugiyono. (2012). Metodologi Penelitian Kualitatif, Kuantitatif, dan R\&D. Bandung: Alfabeta.

[15] Satini. (2016). "Kemampuan Menulis Karangan Eksposisi dengan Menggunakan Teknik Mind Map Siswa Kelas X SMA Negeri 14 Padang". (online) dalam Gramatika Jurnal Penelitian Bahasa, Sastra Indonesia. Jurnal Gramatika, 2(2), 164-179.

[16] Suhaimi. (2016). "Teaching Writing Skill On Recount Text Based On Brainstroming In The Classroom. (online) Jurnal Ta'dib, Vol. 19, No. 1 (Juni 2016).

[17] Yamin, M. (2007). Kiat Membelajarkan Siswa. Jakarta: Gaung Persada Press. 